IJMS 17 (1), 69-85 (2010)

\title{
ADOPTION OF INTERNET BANKING: THEORY OF THE DIFFUSION OF INNOVATION
}

\author{
KHALIL MD NOR \\ Faculty of Management and Human Resource Development \\ Universiti Teknologi Malaysia \\ J. MICHAEL PEARSON \\ ALTAF AHMAD \\ College of Business \\ Southern Illinois University Carbondale
}

\begin{abstract}
The innovation diffusion theory (IDT) could be considered as one of the earliest theories that attempts to explore factors that influence an individual to adopt an innovation or a new technology. The theory suggests five key beliefs that influence the adoption of any innovation: relative advantage, complexity, compatibility, trialability, and observability. The purpose of this study was to test part of IDT's attributes empirically. We used Internet banking as the innovation or the targeted technology. We surveyed 1164 business and MBA students in four public universities in Malaysia. Structural equation modelling was used to analyse the data. The results showed that relative advantage, compatibility, and trialability have a significant effect on attitude. Consequently, attitude significantly affects the intention to use Internet banking. Based on the findings, implications to practice are offered.
\end{abstract}

Keywords: Technology acceptance; innovation diffusion theory; Internet banking.

\begin{abstract}
ABSTRAK
Teori diffusi inovasi (TDI) merupakan antara teori awal yang digunakan untuk mengkaji faktor yang mempengaruhi individu menguasai sesuatu inovasi atau teknologibaru. Teori ini mengutarakan lima kepercayaan utama yang mempengaruhi pemilihan sesuatu inovasi: kelebihan relatif, kerumitan, keserasian, boleh dicuba dan dapat dilihat. Tujuan kajian ini adalah untuk menguji secara empirikal sebahagian daripada atribut teori difusi inovasi ini. Perbankan internet telah dijadikan sebagai inovasi atau teknologi yang dikaji. Penyelidik melakukan tinjauan ke atas
\end{abstract}


1154 pelajar jurusan perniagaan dan sarjana pentadbiran perniagaan di empat buah universiti awam di Malaysia. Model persamaan struktur digunakan untuk menganalisis data. Kajian menunjukkan faktor kelebihan relatif, keserasian, dan boleh dicuba mempunyai kesan signifikan dengan sikap. Sikap pula mempunyai kesan signifikan dengan niat menggunakan perbankan internet. Berdasarkan keputusan kajian, implikasi praktikal diutarakan.

Kata kunci: Penerimaan teknologi; teori difusi inovasi; perbankan internet.

\section{Introduction}

The theory of diffusion of innovation (IDT) (Rogers, 1983) could be considered as one of the earliest theories that has attempted to explore factors that may influence an individual to adopt an innovation or a new technology. The main thesis of this theory is that innovation adoption is a process of uncertainty reduction. To reduce uncertainty about the new technology, individuals will gather and synthesise information about the technology. The result of this process is beliefs about using the technology. These beliefs then cause individuals to accept or reject the technology.

Rogers (1995) suggested five key beliefs affecting the adoption of any innovation. First is relative advantage, which he defines as "the degree to which an innovation is perceived as being better than the idea it supersedes" (p. 212). According to Rogers, relative advantage requires the adopter to analyse the costs and benefits of using an innovation, which can be expressed economically, socially, or in other ways. Relative advantage is basically analogous to usefulness as used by Davis, Bagozzi, and Warshaw (1989) in their technology acceptance model (TAM). Second is compatibility, which is defined as "the degree to which an innovation is perceived as consistent with the existing values, past experiences, and the needs of potential" (p. 224). Compatibility is evaluated relative to the adopter's socio-cultural values and beliefs, previously introduced ideas, and client needs for innovation. In the context of Internet banking, we feel that if the technology is consistent with - their current ways of doing financial transactions and the technology does not go against their current values, the technology has a higher chance to be accepted.

Third is complexity, which is defined as "the degree to which an innovation is perceived as relatively difficult to understand and use" (p. 242). Complexity reflects the level of physical or mental effort necessary to use an innovation. This belief is the opposite of ease of use as adopted by Davis et al. (1989) in TAM. The fourth belief is trialability, which is defined as "the degree to which an innovation may be experimented with on a limited basis" (p. 243). 
Trialability allows the adopter to test drive an innovation so that it gives meaning to the adopter. The final belief is observability, which is defined as "the degree to which the results of an innovation are visible to others" ( $p$. 244).

The purpose of this study was to test IDT's attributes empirically. We used Internet banking as the innovation or the targeted technology. With the exception of observability, we included and tested all other IDT beliefs in this study. Observability was excluded in this study mainly due to the nature of the targeted technology chosen, i.e. Internet banking. We felt individuals generally conduct Internet banking transactions privately and that such actions would not be observable and visible to others (Tan \& Teo, 2000). In addition, since the construct complexity is the opposite of ease of use, we have adopted ease of use as the alternate construct for complexity. In sum, putting it in the context of Internet banking and IDT, we hypothesised that all four beliefs (i.e., relative advantage, compatibility, ease of use, and trialability) positively affect an individual's attitude toward using Internet banking and consequently attitude positively affects the intention to use the technology. The research model for this study is shown in Figure 1.

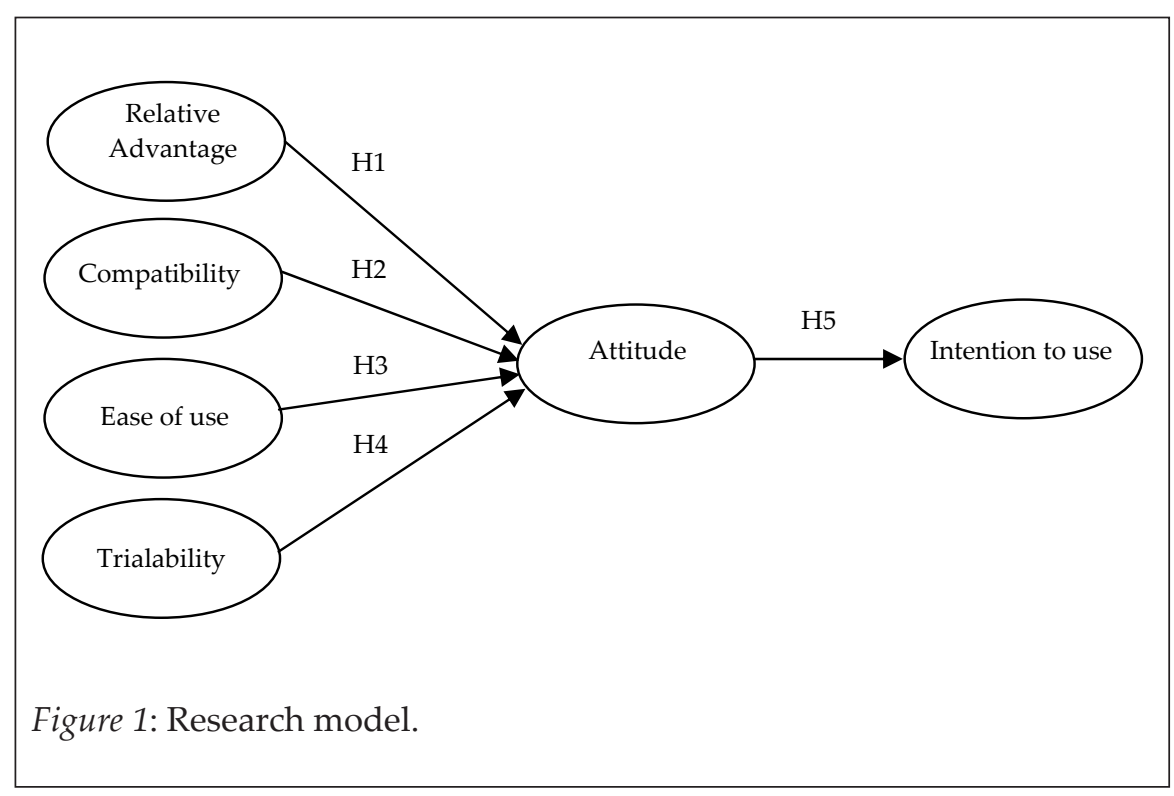

There are five hypotheses in this study.

Hypothesis 1: Relative advantage of using Internet banking positively affects the attitude toward using the technology. 
Hypothesis 2: Compatibility of Internet banking with one's values positively affects the attitude toward using the technology.

Hypothesis 3: Ease of use of Internet banking positively affects the attitude toward using the technology.

Hypothesis 4: Trialability of Internet banking positively affects the attitude toward using the technology.

Hypothesis 5: Attitude about Internet banking positively affects the intention to use the technology.

\section{Previous Studies}

Internet banking has attracted a considerable amount of attention in relation to studying factors of adoption. It has been approached extensively using Davis et al.'s (1989) TAM (Al Sukkar \& Hasan, 2005; Pikkarainen, Pikkarainen, Karjaluoto, \& Pahnila, 2004; Cheng, Lam, Yeung, 2006) as well as Azjen's (1991) Theory of Planned Behaviour (TPB) (Shih \& Fang, 2004; Jaruwachiranthanakul \& Fink, 2005). Adoption of Internet banking has also been studied by looking at characteristics of potential adopters e.g. consumer beliefs (Karjaluoto, Mattila, \& Pento, 2002 ) and categorisations of adopters, (Ainin, Lim, \& Wee, 2005; Ravi, Carr, \& Sagar, 2006; Maenpaa, 2006). This paper's use of IDT adds to the Internet banking adoption stream and expands the range of applications investigated via IDT.

A literature search indicated that the applications of IDT have been varied. For instance, IDT was utilised in instrument development (Moore \& Benbasat, 1991), used as part of research models (Taylor \& Todd, 1995; Tan \& Teo, 2000), and compared to other theories such as TAM (Karahanna, Straub, \& Chervany 1999, Plouffe, Hulland, \& Vandenbosch, 2001). IDT has also been widely used in IT related technologies. It has been tested on operating systems (Karahanna et al., 1999), smart card readers (Plouffe et al., 2001), information systems processes (Mustonen-Ollila \& Lyytinen, 2003), as well as Internet banking (Tan \& Teo, 2000; Gerrard \& Cunningham, 2003; Kolodinsky, Hogarth, \& Hilgert, 2004). Several of these studies are discussed in this section.

Moore and Benbasat (1991) used IDT's attributes to develop an instrument that can be used to measure the perceptions of adopting an information technology. In this instrument, Moore and Benbasat kept four of Rogers' innovation characteristics, namely relative advantage, compatibility, ease of use (complexity), and trialability. They also added two additional constructs (voluntariness and image) and split observability into two separate constructs (result demonstrability and visibility). The result was a valid and reliable 38-item instrument made up of eight unique scales.

72 IJMS 17 (1), 69-85 (2009) 


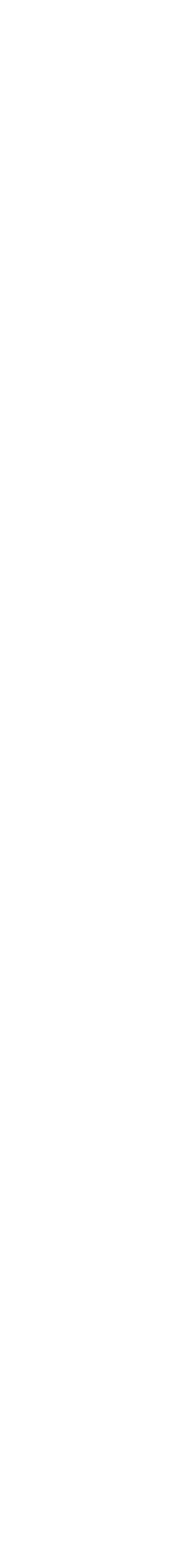

The IDT attributes were also used to predict computing resource centre usage. In a study involving 786 business school students, Taylor and Todd (1995) used three IDT attributes (relative advantage, ease of use, and compatibility) as part of their research model to predict attitude toward using the centre. The results indicated that these attributes explained about $76 \%$ of the variance in attitude and in terms of hypothesised paths, only perceived usefulness significantly affected attitude. Kolodinsky et al. (2004) studied the adoption of electronic banking (including automated payments and phone banking) in the US and found mixed support for IDT attributes.

Parthasarathy and Bhattacherjee (1998) used the IDT to examine the post-adoption behaviour among users of online services. In this study, they postulated that there are distinct factors that discriminate between continuers and discontinuers of an innovation. Factors examined were communication influence, utilisation level, relative advantage, ease of use, compatibility, and network externalities. The study found that all factors were significant discriminators except utilisation (weakly supported) and ease of use. Specifically on the IDT attributes, the results indicated that discontinuers perceived the service as less useful and less compatible with their work habits.

Karahanna et al. (1999) combined IDT and TRA to examine factors that influence Windows 3.1 adoption across time. Based on Moore and Benbasat's (1991) instrument, seven attributes were tested: perceived usefulness (relative advantage), image, compatibility, ease of use, visibility, result demonstrability, and trialability. The study found that among the potential adopters, all of the attributes except image significantly affected the adoption attitude. For users, only perceived usefulness and image were found significant.

As in Taylor and Todd's (1995) study, Tan and Teo (2000) utilised four IDT attributes (relative advantage, compatibility, complexity, and trialability) as part of their research model to predict intention to adopt Internet banking services. They found that relative advantage, compatibility, and trialability significantly affected the intention to use Internet banking, whereas complexity was not significant. Plouffe et al. (2001) compared the IDT with the technology acceptance model (TAM) in predicting the adoption intention of smart card readers among retailers. Like Karahanna et al. (1999), seven attributes were tested in this study. The study found that relative advantage, compatibility, image, visibility, and trialability significantly explained the intention to adopt the technology. In terms of comparison between the two models, the study found that IDT and TAM explained $45 \%$ and $36.2 \%$ of the variance in intention to adopt, respectively. 
IDT was also used in a study of online consumers' intention to use virtual stores (Chen, Gillenson, \& Sherrell, 2002). The study was conducted on 253 registered users of a non-profit organisation and three news groups. In this study, an IDT's attribute (compatibility) was added into TAM. They found that compatibility between using a virtual store and a consumer's belief, values, and needs positively affected one's attitude toward using virtual stores. In another study, Lau (2002) utilised IDT's attributes to predict brokers adoption of online trading in Hong Kong. The study found that perceived usefulness, perceived ease of use or complexity, relative advantage, compatibility, and observability were significantly correlated with attitude of using the system.

Deriving attributes from TAM and IDT, Hardgrave, Davis, and Riemenschneider, (2003) conducted a study to identify factors that influence application developers' intention to follow a software development methodology. Three attributes, usefulness (relative advantage), complexity, and compatibility were used as part of the research model. The results showed that usefulness and compatibility significantly influenced the intention. Complexity was not significant.

Gerrard and Cunningham (2003) used the IDT in a study of Internet banking diffusion in Singapore. They found that adopters of Internet banking perceived the service as more convenient, less complex, and more compatible to them. Finally, in a comprehensive review on technology acceptance models, Venkatesh, Morris, Davis , and Davis, (2003) found that relative advantage, ease of use, result demonstrability, trialability, visibility, image, compatibility, and voluntariness together explained approximately $54 \%$ and $47 \%$ of the variance in intention in voluntary and mandatory settings, respectively. In terms of the hypothesised paths, two IDT's attributes (relative advantage and ease of use) were significant in predicting intention both in voluntary and mandatory settings. Image was a significant predictor of the intention only in mandatory settings.

ㅁ

\begin{abstract}
Methodology
Subjects for this study were final year undergraduates and MBAs at four public universities in West Malaysia. MBAs were included in this study with the objective to get Internet banking intention responses from users who have experience with a wider range of banking services. Unlike MBAs, undergraduate students experience with banking activities is probably limited to certain banking services. Thus, by selecting both MBAs and undergraduates as respondents in this study it is hoped that there will be
\end{abstract}

74 IJMS 17 (1), 69-85 (2009) 
increase the validity of the study as the respondents were represented by a broader spectrum of banking customers.

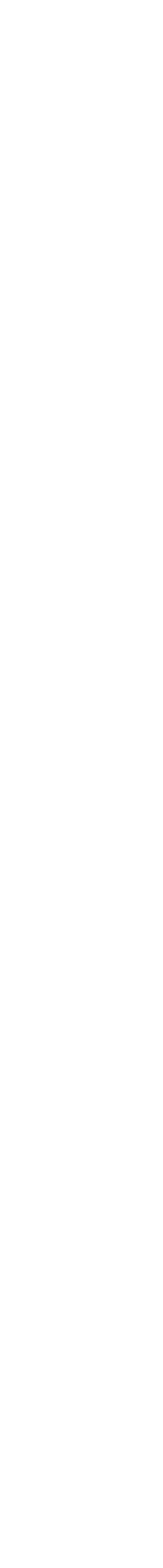

We used a paper-based questionnaire as the instrument for the survey. We had chosen this approach as opposed to online survey in distributing the questionnaire, so as to ensure well distributed response from the target population. The online survey might result in a response from only a certain segment of the target population who has easy access to the Internet and being more Internet savvy. Thus, this might affect the validity of the study. All items intended to measure the variables in this study were adopted from previously validated instruments (Taylor \& Todd, 1995; Bhattacherjee, 2000; Moore \& Benbasat, 1991; Tan \& Teo, 2000). The survey was administered with the help of administrators at each business school. The survey was given to professors, who then distributed the instrument to students in their class. Stuctural equation modeling (SEM) was used to analyse the data. A confirmatory factor analysis was performed to assess the reliability and validity of the measurement model before we tested the structural model.

\section{Analysis}

The target population of this study was final year undergraduates and MBAs at four public universities in Malaysia, i.e. one university in the north, one in the south, and two universities in the central part of Malaysia. A total of 1350 questionnaires were distributed representing more than $60 \%$ of the estimated population size, which were 2000 respondents. For each university, we had distributed about 330 questionnaires. Of these 1,164 questionnaires were returned, indicating $86.2 \%$ rate of return. Out of 1164 returned questionnaires, 326 responses were from current users of Internet banking. We believe factors that affect an individual's intention to adopt an innovation might be different among users and non-users. By grouping both users and non-users together, the validity of the findings might be affected. Hence, we chose only one group, i.e. non-users for the analysis and the responses from users were excluded. Missing data analysis resulted in 21 cases being dropped. The final count for this study was 817 cases.

Table 1 provides the respondents' demographic profile. About $21 \%$ of the respondents were male and $79 \%$ were female. Their age ranged from 20 to 50 with mean age of about 22 . The majority of them were undergraduates representing $92 \%$ of the total sample. With respect to their racial identity, about $50 \%$ were Malay, $42 \%$ were Chinese, $5 \%$ were Indian, and $3 \%$ were others. 
Table 1

Demographic Profile $(n=817)$

\begin{tabular}{|c|c|c|c|}
\hline Variable & Category & Frequency & Percentage $(\%)$ \\
\hline \multirow[t]{2}{*}{ Gender } & Male & 174 & 21.3 \\
\hline & Female & 643 & 78.7 \\
\hline \multirow[t]{3}{*}{ Age } & $20-21$ & 433 & 53.0 \\
\hline & $22-23$ & 280 & 34.3 \\
\hline & $23+$ & 104 & 12.7 \\
\hline \multirow[t]{2}{*}{ Class standing } & Under graduate & 752 & 92.0 \\
\hline & Masters & 65 & 8.0 \\
\hline \multirow[t]{4}{*}{ Race } & Malay & 404 & 49.5 \\
\hline & Chinese & 341 & 41.7 \\
\hline & Indian & 45 & 5.5 \\
\hline & Others & 27 & 3.3 \\
\hline
\end{tabular}

A confirmatory factor analysis was conducted to assess the reliability and validity of the measurement model. Following Hair, Anderson, Tatham, and Black's (1998) recommendation, we first assessed the measurement model in terms of its overall fit to the data. We examined factor loadings for each items. Following Hair et al.'s (1998) suggested guidelines, we dropped two items (EU10 and CA15) with indicator reliabilities below 0.5. The descriptive

- statistics of these items, their loadings, and reliabilities are shown in Table 2.

Table 2

Items Dropped (Indicator Reliability Less Than 0.5)

\begin{tabular}{|c|c|c|c|c|c|c|}
\hline 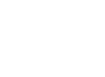 & Code & Item & Mean & SD & $\begin{array}{l}\text { Factor } \\
\text { Loadings }\end{array}$ & $\begin{array}{l}\text { Indicator } \\
\text { Reliability }\end{array}$ \\
\hline 무 & EU10 & $\begin{array}{l}\text { I think it is easy to become skillful at } \\
\text { using Internet banking. }\end{array}$ & 5.02 & 1.07 & 0.68 & 0.46 \\
\hline & CA15 & $\begin{array}{l}\text { I think using Internet banking to } \\
\text { conduct banking transactions is } \\
\text { compatible with my current situation. }\end{array}$ & 4.75 & 1.20 & 0.68 & 0.47 \\
\hline
\end{tabular}

Note. Scale: 1 = strongly disagree, 7 = strongly agree.

We ran a confirmatory factor analysis using the retained items. Table 3 shows the overall fit of the measurement model. The $\chi^{2}$ was 1223.57 . In addition, the NFI, NNFI, CFI, and RMSEA values indicated an acceptable fit

76 IJMS 17 (1), 69-85 (2009) 
and exceed the common acceptance levels as suggested by Hair et al. (1998). These results suggested that we could proceed to evaluate the reliability and validity of the measurement model.

Table 3

Fit Indices for the Measurement Model

\begin{tabular}{cccccc}
\hline$\chi^{2}$ & d.f. & NFI & NNFI & CFI & RMSEA \\
\hline 1223.576 & 335 & 0.93 & 0.94 & 0.95 & $0.057^{\mathrm{a}}$ \\
\hline
\end{tabular}

Notes. d.f. $=$ degrees of freedom.

$\mathrm{NFI}=$ Bentler-Bonett normed fit index .

NNFI = Bentler-Bonett non-normed fit index

$\mathrm{CFI}=$ Comparative fit index.

RMSEA = Root mean square error of approximation.

Recommended value: NFI, NNFI \& CFI $>0.90$ and RMSEA $<0.05-0.08$

a $90 \%$ confidence interval $(0.054,0.060)$.

The composite reliability was calculated to assess the internal consistency of the construct indicators. Higher composite reliability indicates higher consistency of indicators in their measurement (Hair et al., 1998). As shown in Table 4, all constructs had composite reliability greater than 0.80, which was higher than the benchmark of 0.70 as recommended by Hair et al. (1998).

In addition to the composite reliability measures, the average variance extracted was also computed. Higher variance extracted values indicate higher percentage of the variance of the latent construct is explained by its indicators (Chen et al., 2002). As shown in Table 4, all constructs values were above 0.5 , the guideline suggested by Hair et al. (1998).

Table 4

Composite Reliability and Average Variance Extracted

\begin{tabular}{lcc}
\hline Latent Variables & Composite Reliability & Average Variance Extracted \\
\hline Relative advantage & 0.90 & 0.65 \\
Ease of use & 0.85 & 0.60 \\
Compatibility & 0.87 & 0.64 \\
Trialability & 0.91 & 0.67 \\
Attitude & 0.94 & 0.76 \\
Intentions & 0.95 & 0.80 \\
\hline
\end{tabular}

Having assessed the measurement model, we tested the structural model. We fit the base model first. Examining the goodness of fit of the base model, however, revealed that the model did not fit the data very well (Table 5). NFI and NNFI were less than 0.90 , below the recommended level suggested by Hair et al. (1998). 
Table 5

Fit Indices for the Base Model

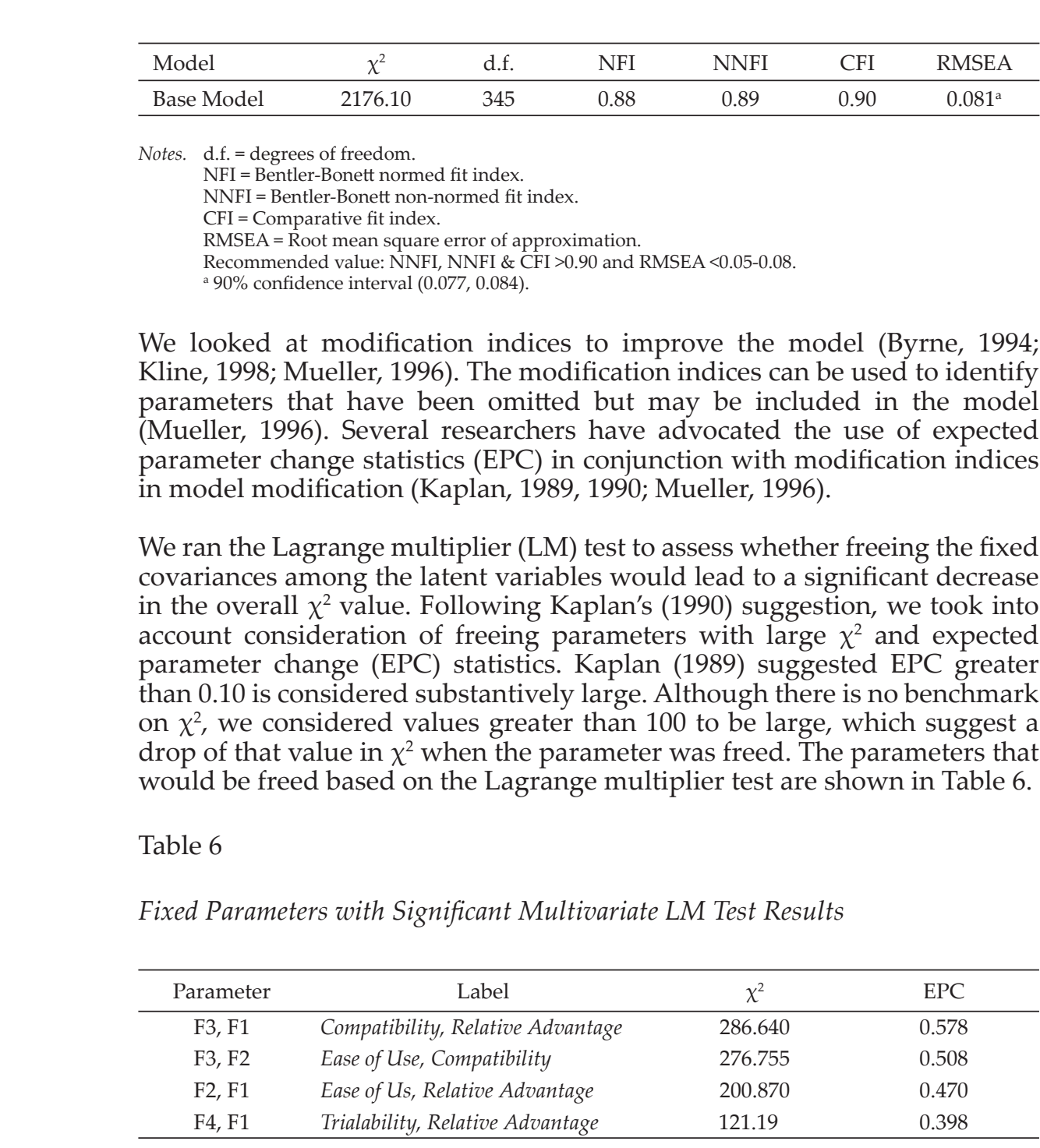

We ran the modified structural model again, freeing the above parameters. As expected, the modified (final) structural model demonstrated an improvement in the overall model fit. The overall $\chi^{2}$ dropped from 2176.1 to 1395.71 (Table 7). In addition, the NFI, NNFI, CFI, and RMSEA values of the modified model also reflected a better fit and within the recommended levels (Hair et al., 1998).

78 IJMS 17 (1), 69-85 (2009) 
Table 7

Fit Indices for the Structural Model

\begin{tabular}{lcccccc}
\hline Model & $\chi^{2}$ & d.f. & NFI & NNFI & CFI & RMSEA \\
\hline Base Model & 2176.1 & 345 & 0.88 & 0.89 & 0.90 & $0.081^{\mathrm{a}}$ \\
Modified (Final) & 1395.7 & 341 & 0.93 & 0.94 & 0.94 & $0.062^{\mathrm{b}}$ \\
\hline
\end{tabular}

Notes. d.f. $=$ degrees of freedom.

NNFI = Bentler-Bonett non-normed fit index

IFI = Bollen fit index.

$\mathrm{CFI}=$ Comparative fit index.

RMSEA = Root mean square error of approximation.

Recommended value: NNFI, NNFI \& CFI $>0.90$ and RMSEA $<0.05-0.08$

a $90 \%$ confidence interval $(0.077,0.084)$.

b $90 \%$ confidence interval $(0.058,0.065)$

A graphic representation of the final structural model, which includes the standardised path coefficients, is displayed in Figure 2.

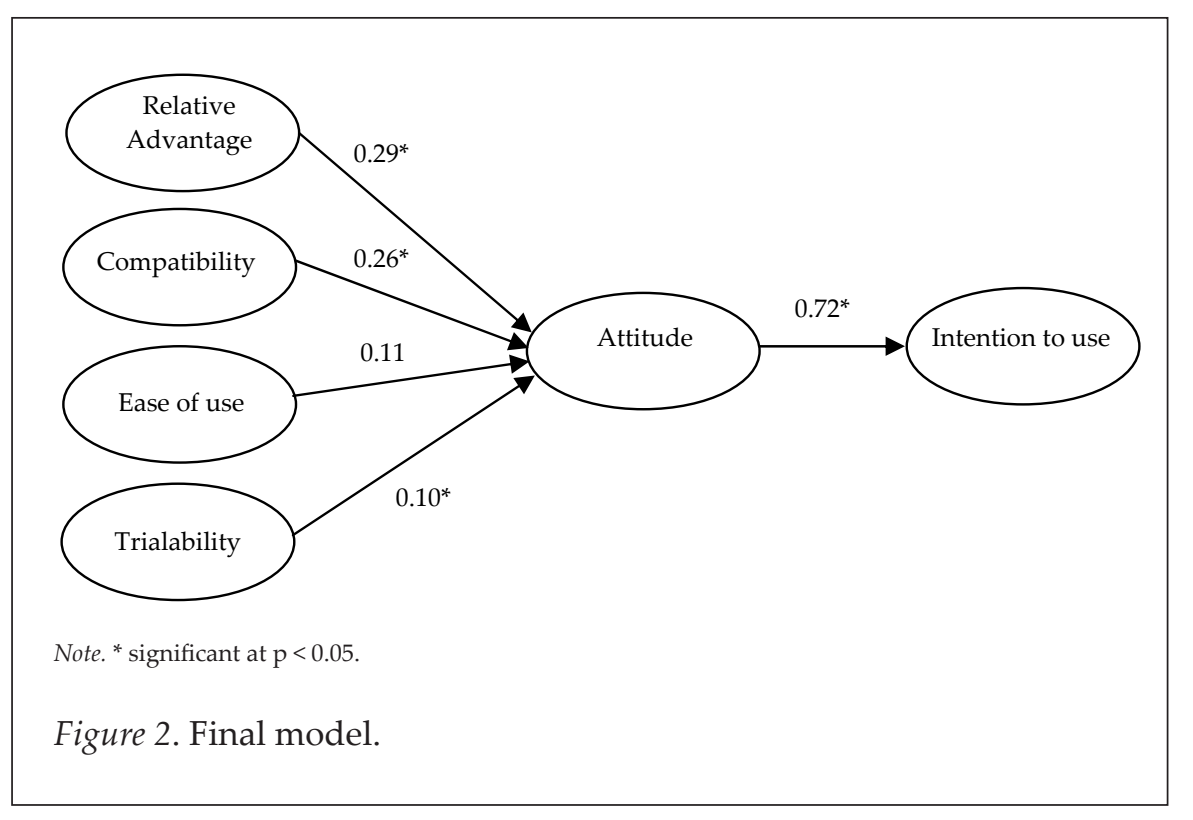

\section{Discussion and Implication to Practice}

As expected, relative advantage $(\beta=0.29, p<0.05)$ was found to have a significant positive effect on attitude toward using Internet banking. This is consistent with prior research on information system acceptance (Horton, 
Buck, Waterson, \& Clegg, 2001; Morris \& Dillon, 1997). The significant effect of perceived relative advantage on attitude is not surprising. The benefits of using Internet banking are numerous. Its benefits include faster and convenient execution of financial transactions, lower economic cost (reduced commuting, checking, and postage expenses), and convenient online access to financial information. Therefore, Hypothesis 1 was supported.

As expected, the result of this study supported Hypothesis 2 that perceived compatibility $(\beta=0.26, p<0.05)$ affects the attitude toward using the technology. The linkage between compatibility and attitude has also been found in other studies (Chen et al., 2002; Tan \& Teo, 2000). This finding suggested that a positive attitude toward Internet banking can be developed by highlighting the compatibility of the technology with individual existing values and needs. Banks can promote the act of doing financial transactions online being part of the current and future lifestyle. Performing financial transactions through Internet banking can be projected to fit well with the modern lifestyle.

Surprisingly, Hypothesis 3 was not supported in this study. The results showed that perceived ease of use $(\beta=0.11)$ does not have a significant effect on the attitude toward using the technology. This is contrary to findings of several studies (Kolodinsky et al., 2004; Chen et al., 2002; Lau, 2002; Taylor \& Todd, 1995). We believe the unsupported hypothesis might be due to the selection of the subjects in this study. The subjects for this study were undergraduates and MBAs, most of whom were computer literate and very comfortable with using the technology. Therefore, the issue of ease of use might not have arisen. This is supported by Ainin et al.'s (2005) study of e-banking adopters in Malaysia, which revealed that users perceived using e-banking as easy.

Hypothesis 4 was supported in this study. Trialability $(\beta=0.10, p<0.05)$ of Internet banking has been found to have a significant positive effect on the attitude toward using the technology. These results are in contrast to Kolodinsky et al. (2004), who did not find support for trialability. However, - our finding suggested that a positive attitude toward Internet banking can be built by providing potential users the opportunity to test-drive the technology. Banks could provide step-by-step demonstrations on how to use Internet banking as well as provide simulated experiences of Internet banking use, thus affording users the chance of trying the technology.

Finally, as expected, attitude $(\beta=0.72, p<0.05)$ was found to have a significant positive effect on the intention to use Internet banking. This finding was consistent with other studies in the information system field (Chang \& Cheung, 2001; Davis et al., 1989) and the Internet banking domain (Liao, 


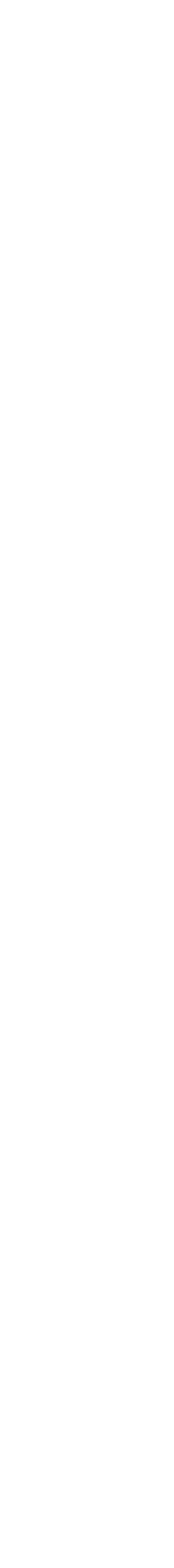

Shao, Wang, \& Chen, 1999; Suh \& Han, 2002). The significant results suggest a positive evaluation of Internet banking by individuals would lead to their intention to use the technology. The result suggested that the formation of positive attitude about Internet banking should take place before the technology can be accepted.

As found in this study, three factors significantly affect attitude (relative advantage, compatibility, and trialability). Banks can use these factors to create a positive attitude amongst its customers toward Internet banking. Greater awareness of these factors should facilitate the formation of positive attitudes about the technology, consequently leading to higher intention to use the technology. The results of the hypotheses are summarised in Table 8.

Table 8

Hypotheses Results

\begin{tabular}{lll}
\hline \multicolumn{3}{c}{ Hypotheses } \\
\hline H1 & $\begin{array}{l}\text { Perceived relative advantage of using Internet banking positively } \\
\text { affects the attitude toward using the technology. }\end{array}$ & Supported \\
H2 & $\begin{array}{l}\text { Perceived compatibility of Internet banking with one's values } \\
\text { positively affects the attitude toward using the technology. }\end{array}$ & Supported \\
H3 $\quad \begin{array}{l}\text { Perceived ease of use of using Internet banking positively affects } \\
\text { the attitude toward using the technology. }\end{array}$ & Not supported \\
H4 $\begin{array}{l}\text { Trialability of Internet banking positively affects the attitude } \\
\text { toward using the technology. }\end{array}$ & Supported \\
H5 & $\begin{array}{l}\text { Attitude about Internet banking positively affects the intention to } \\
\text { use the technology. }\end{array}$ & Supported \\
\hline
\end{tabular}

\section{Conclusion and Recommendations}

This study found that relative advantage, compatibility, and trialability significantly affect one's attitude toward Internet banking. This study has also found that positive attitude about Internet banking should take place before the technology can be accepted. To build positive attitude toward Internet banking, banks may need to publicise the benefits associated with the technology, such as faster and convenient execution of financial transactions, and lower economic cost. Internet banking also needs to be highlighted as compatible with an individual's existing values and needs. For instance, banks could project in their Internet banking promotional activities that performing financial transactions online is compatible and consistent with the way people do things nowadays. Internet banking

IJMS 17 (1), 69-85 (2009) 8 
aligns well with their current lifestyle where communication, work, and entertainment are done online and feeling of urgency in terms of getting work done fast and conveniently. Banks may also need to provide opportunity for their customers to "test-drive" the technology by providing possibility for potential customers to use Internet banking.

Some of the results of this study were in contrast with the results that other studies have obtained. This diversity of findings supports the need for further investigation into diffusion factors of Internet banking that supplements existing research.

\section{Limitation}

This study was not without limitation. One potential limitation was the use of students as the subjects for the study. The respondents of the study were students in four public universities in Malaysia. Using students as the respondents may limit the generalisability of the findings. The data collected were represented by a limited fraction of the population, i.e. students and not from the general public. Although students are good surrogates for banking customers because they typically are current banking customers, questions remain concerning the generalisability of the results to a larger population. Thus, the generalisability of the findings from this study needs to be taken cautiously. Future study may consider surveying the general public so that the issue of generalisability can be mitigated.

\section{References}

Ainin, S., Lim, C.H., \& Wee, A. (2005). Prospects and challenges of e-banking in Malaysia. Electronic Journal on Information Systems in Developing Countries, 22(1), 1-11.

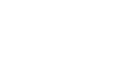

Al Sukkar, A., \& Hasan, H. (2005). Toward a model for the acceptance of Internet banking in developing countries. Information Technology for Development, 11(4), 381-398.

Azjen, I. (1991). The theory of planned behaviour. Organisational Behaviour and Human Decision Processes, 50, 179-211.

Bhattacherjee, A. (2000). Acceptance of e-commerce services: The case of electronic brokerages. IEEE Transactions on Systems, Man, and Cybernetics-Part A: Systems and Humans, 30(4), 411-420.

Byrne, B.M. (1994). Structural equation modelling with EQS and EQS/Window: Basic concepts, applications, and programming. Thousand Oaks, CA: Sage Publications.

82 IJMS 17 (1), 69-85 (2009) 
Chang, M.K., \& Cheung, W. (2001). Determinant of the intention to use Internet/WWW at work: A confirmatory study. Information $\mathcal{E}$ Management, 39(1), 1-14.

Cheng, T.C.E., Lam, D.Y.C., \& Yeung, A.C.L., (2006). Adoption of Internet banking: An empirical study in Hong Kong. Decision Support Systems, 42(3), 1558-1572.

Chen, L., Gillenson, M.L., \& Sherrell, D.L. (2002). Enticing online consumers: An extended technology acceptance perspective. Information and Management, 39(8), 705-719.

Davis, F.D., Bagozzi, R.P., \& Warshaw, P.R. (1989). User acceptance of computer technology: A comparison of two theoretical models. Management Science, 35(8), 982-1003.

Gerrard, P., \& Cunningham, J. B. (2003). The diffusion of Internet banking among Singapore consumers. International Journal of Bank Marketing, 21(1), 16-28.

Hair, J., Anderson, R., Tatham, R., \& Black, W. (1998). Multivariate data analysis. Upper Saddle River, New Jersey: Prentice Hall.

Hardgrave, B.C., Davis, F.D., \& Riemenschneider, C.K. (2003). Investigating determinants of software developers' intentions to follow methodologies. Journal of Management Information Systems, 20(1), 123151.

Horton, R.P., Buck, T., Waterson, P.E., \& Clegg, C.W. (2001). Explaining intranet use with the technology acceptance model. Journal of Information Technology, 16(4), 237-249.

Jaruwachiranthanakul, B., \& Fink, D. (2005). Internet banking adoption strategies for a developing country: The case of Thailand. Internet Research, 15(3), 295-311.

Kaplan, D. (1989). Model modification in covariance structure analysis: Application of the expected parameter change statistics. Multivariate Behavioral Research, 24(3), 285-305.

Kaplan, D. (1990). Evaluating and modifying covariance structure models: A review and recommendation. Multivariate Behavioral Research, 25(2), 137-155.

Karahanna, E., Straub, D.W., \& Chervany, N.L. (1999). Information technology adoption across time: A cross-sectional comparison of pre-adoption and post-adoption beliefs. MIS Quarterly, 23(2), 183-213.

Karjaluoto , H ., Mattila , M., \& Pento , T . ( 2002 ). Electronic banking in Finland: Consumer beliefs and reactions to a new delivery channel. Journal of Financial Services Marketing, 6(4), 346 - 361.

Kline, R.B. (1998). Principles and practice of structural equation modeling. New York: New York The Guilford Press. 
Kolodinsky, J.M., Hogarth, J.M., \& Hilgert, M.A. (2004). The adoption of electronic banking technologies by us consumers. International Journal of Bank Marketing, 22(4/5), 238-259.

Lau, S.M. (2002). Strategies to motivate brokers adopting on-line trading in Hong Kong financial market. Review of Pacific Basin Financial Markets and Policies, 5(4), 471-489.

Liao, S., Shao, Y P., Wang, H., \& Chen, A. (1999). The adoption of virtual banking: An empirical study. International Journal of Information Management, 19(1), 63-74.

Maenpaa, K., (2006). Clustering the consumers on the basis of their perceptions of Internet banking services. Internet Research, 16(3), 304322.

Moore, G.C., \& Benbasat, I. (1991). Development of an instrument to measure the perceptions of adopting an information technology innovation. Information Systems Research, 2(3), 192-222.

Morris, M.G., \& Dillon, A. (1997). How user perceptions influence software use. IEEE Software, 14(4), 58-65.

Mueller, R.O. (1996). Basic principles of structural equation modeling. New York: New York Springer-Verlag.

Mustonen-Ollila, E., \& Lyytinen, K. (2003). Why organisations adopt information system process innovations: A longitudinal study using diffusion of innovation theory. Information Systems Journal, 13(3), 275297.

Parthasarathy, M., \& Bhattacherjee, A. (1998). Understanding post-adoption behaviour in the context of online services. Information Systems Research, 9(4), 362-379.

Pikkarainen, T., Pikkarainen, K., Karjaluoto, H., \& Pahnila, S. (2004). Consumer acceptance of the technology acceptance model. Internet Research, 14(3), 224-235.

Plouffe, C.R., Hulland, J.S., \& Vandenbosch, M. (2001). Research report: Richness versus parsimony in modeling technology adoption decisions - understanding merchant adoption of a smart card-based payment system. Information Systems Research, 12(2), 208-222.

Ravi, V., Carr, M., \& Sagar, N. V. (2006). Profiling of Internet banking users in India using intelligent techniques. Journal of Services Research, 6(2), 61-73.

Rogers, E.M. (1983). The diffusion of innovations. New York: New York Free Press.

Rogers, E.M. (1995). Diffusion of innovations. New York: New York Free Press.

Shih, Y., \& Fang, K. (2004). The use of a decomposed theory of planned behaviour to study Internet banking in Taiwan. Internet Research, 14(3), 213-223.

84 IJMS 17 (1), 69-85 (2009) 
Suh, B., \& Han, I. (2002). Effect of trust on customer acceptance of Internet banking. Electronic Commerce Research and Applications, 1, 247-263.

Tan, M., \& Teo, T.S.H. (2000). Factors influencing the adoption of Internet banking. Journal of the Association for Information Systems, 1(1), 1-42.

Taylor, S., \& Todd, P. (1995). Understanding information technology usage: A test of competing models. Information Systems Research, 6(2), 144176.

Venkatesh, V., Morris, M.G., Davis, G.B., \& Davis, F.D. (2003). User acceptance of information technology: Toward a unified view. MIS Quarterly, 27(3), 425-478. 